УДК $811.161 .2 ’ 27$

L. A. Bilokonenko

\title{
INTERPERSONAL VERBAL CONFLICT IN UKRAINIAN ENVIRONMENT
}

\author{
Білоконенко Л. А. Міжособистісний мовний конфлікт в українському \\ середовищі.
}

У статті узагальнено результати соціологічного дослідження. За підсумками анкетування було визначено, що респонденти цілеспрямовано декларують свою «неконфліктність», висловлюються проти вживання мовних конфліктогенів, уважають, що в конфлікті треба проявляти емпатію, емоційну витримку, уникати претензій на підвищених тонах; основними причинами антикультурного спілкування називають індивідуально-психологічні, характерологічні передумови та рівень емоційності особи.

Визнають, що м'які типи мовленнєвих тактик допомагають прийти до розв'язання конфлікту, 90\% респондентів, стратегію уникнення сприймають як важливу більше половини опитаних, не є пріоритетною стратегія боротьби для 90\%, уміння знаходити компроміс задля завершення суперечки $є$ значущим для 80\%. На стадії завершення шукають примирення більше 95\% респондентів, вони стверджують, що ця стратегія передбачає аналіз мовленнєвих тактик, що призвели до його ескалації.

Проанкетовані зазначають, що найважливішими когнітивними конфліктними чинниками $€$ ті, що сформовані життєвими переконаннями й особистими уподобаннями людини; активізація певного сценарію розвитку конфлікту встановлюється факторами, пов'язаними зі структурами життєвих принципів особи, іiі поглядами, орієнтирами, інтересами. До прагматичних чинників головно зараховані ті, що засвідчують «змістовий саботаж», коли людина свідомо ігнорує зміст висловлень співрозмовника.

Відповіді респондентів доводять, що усвідомлення етнокультурної, когнітивної і прагматичної сутності міжособистісного мовного конфлікту актуалізується завдяки конфліктному життєвому досвіду індивіда. Ці знання $є$ основою для визначення «значущості» кожного конфлікту, для інтерпретації тактик комунікативних дій опонента. Уважається, що успішність взаємодії суб'єктів зумовлюється певними мовними законами, які є частиною морально-етичних норм поведінки членів соціуму.

Ключові слова: міжособистісний мовний конфлікт, конфліктоген, мовленнєві тактики, когнітивний і прагматичний чинники, морально-етичні норми.

Белоконенко Л. А. Межличностный речевой конфликт в украинском контексте.

В статье приводятся результаты социологического исследования. Было определено, что восприятие этнокультурной, когнитивной и прагматической сущности межличностного речевого конфликта актуализируется благодаря конфликтному жизненному опыту респондентов. Эти знания - основа для определения «значимости» каждого конфликта, для интерпретации тактик коммуникативных действий оппонента. Опрошенные считают, что успешность коммуникации субъектов формируется языковыми законами, которые являются 
частью морально-этических норм социума.

Ключевые слова: межличностный речевой конфликт, конфликтоген, речевые тактики, когнитивный и прагматический факторы, морально-этические нормы.

Bilokonenko L. A. Interpersonal verbal conflict in Ukrainian environment.

The article presents the results of the survey. It was found that respondents' perception of ethno-cultural, cognitive and pragmatic nature of interpersonal verbal conflict actualized because of their "conflict experience". This knowledge was the basis for determining the significance of the conflict, to interpret the tactics of communicative actions of individuals. The respondents believe that the success of the interaction is governed by speech "laws" that are part of the moral and ethical norms of society.

Key words: interpersonal verbal conflict, conflictogen, speech tactics, cognitive and pragmatic factors, moral and ethical standards.

Multifold nature of interpersonal verbal conflict is determined by the fact that it is associated with humanity. The heterogeneity of the phenomenon is the cause of the lack of unanimity in its perception, as a collection of many interrelated features is a challenging problem to be described. That type of conflict combines internal (spiritual, personal, biological) and external (social) factors. Their dialectical interaction determines the nature of man and this phenomenon and behaviours individuals in it. Major trends analysis of the linguistic conflict associated with achievements of sociology, psychology, and philosophy, to which is attached linguistics.

The study of verbal conflict - one of the urgent problems of modern Ukrainian sociolinguistics. They can be studied from different angles, but there is not many works in Ukrainian science $[2 ; 5 ; 6 ; 8]$.

While the description of the factors that cause actions of language in interpersonal conflict, sociolinguistic study of its nature refers to the longterm direction. At the moment, it is at the early learning stages in Ukraine and is also relevant.

Scope of the existence of verbal conflict - interpersonal relationships within the social interaction that takes place with violation of the rules of communication. Failure to comply with the principle of cooperative forms of linguistic orientation conflict conflicting interaction communicants. Wiliness to be opposite the opponent, hostility, intolerance, and lack of interest in it are determined by various factors, including their social roles.

For the analysis of perception interpersonal conflict in the Ukrainian language communicative environment, identifying important national cultural norms and rules of its course, communicative behavior in the use of () L. A. Bilokonenko, 2016. 
certain speech tactics we conducted sociological research on "Perception of interpersonal conflict in Ukrainian society". Hypothesis of the study: perception of verbal conflict in modern Ukrainian society depends on here, national and cultural norms, rules, and traditions; at most cases, communicative behavior at the interpersonal conflict depends on conflict experience.

Socio-demographic characteristics of respondents representing each regions of Ukraine (550 people were questioned): 38\% were males and $62 \%$ females. All respondents were 18 years old or older, from which 18 to 25 year olds $-31 \%$, ages 26 to $50-42 \%$, and those older than $50-27 \%$. Of these the percentages of which, have a secondary or vocational education $52 \%, 28 \%$ of people were with a bachelor degree, and $20 \%-$ were with a specialist degree. It also was determined that more than $20 \%$ are studying in the moment, 55\% - working, and 25\% - working and studying.

Determining the level of conflict helps us to make an important conclusion about the behavior of the respondents to the dispute. This level is characterized by complex influence of psychological, social, psychological, and social factors. According to a survey, it was found that the participants represent themselves as tactful and peaceful people who avoid conflict emergencies at school, at home $-42 \%$. The group who takes part in conflict only if it is necessary, correct the dispute, but can defend themselves $-45 \%$. And conflicting participants $-13 \%$. Between the level of conflict readiness of person and the choice of a strategy and tactics in the conflict there is a connection: person(s) with a high level of conflict readiness often resort to a strategy of struggle and hard and medium verbal tactics. The person(s) with low level of conflict readiness - attempt to avoid, make concessions, and use soft verbal tactics.

The results of the research.

A) In a conflict, the ability for empathy is important in a person. Empathy helps to balance interpersonal relations. Culture of human communication requires the ability to perceive and understand the interlocutor, to establish effective interaction with the target, and focus on the person as an equal partner in communication. However, addressors often use their personal experience to explain the conflict internal state, behavior, words, and emotions leading the recipient to possible subjectivity or errors in interpretation. One's ability for empathy depends on the 
conditions of education, social environment, values, individual traits, and more. The question №1: Do you think that in the conflict you need to empathize with others in part of conflict, to be fair and patient with them, not condemn, kindly and attentively listen; and try to understand your opponent's position? The "yes" responses were - 96\%, "no" garnered a responded of $-2 \%$, and "hard to answer" - 2\%. The question №2: Are you able to empathize with others in part of conflict, fairly and patiently to treat your opponent, not condemn, carefully and kindly listen, and understand their position? Of those polled $41 \%$ clearly said "yes", $17 \%$ believe that they can empathize, but not always. Almost 32\% felt that these attempts have failed them, and $10 \%$ could not answer the question. The "yes" answers to the question №№1-2 had a variance in data of nearly 55\%. The majority surveyed say they believe empathy, attentiveness, and a friendly attitude to the opponent in the conflict are necessary but this ability to recognize what was needed by them was only present in half of respondents.

B) Pauses are required for successful communication and interaction with their role in conflict increases significantly. In verbal conflict parties use pauses due a lesser desire to rhythmically "build" phrase(s) as an opportunity to emphasize the attitude to the situation that may have arisen. Pauses emphasize the importance of following the speaker's remarks. Individual's hesitation in choosing the language used often means they desire to gather their thoughts, consider their own replica, and determine the flow or information that the person can not or does not want to reveal for any reason. Emotional speech of the parties involved sometimes uses longer conflict pauses with their "silence". It's hard not to say something, it is difficult to be heard by an opponent - a pause or break in this sense means a lot. Only when the first party makes it possible for second part to use a pause, eases the condition for thinking. With pauses, intonation, and facial expressions it is possible to manipulate an opponent. If a person is able to listen to the interlocutor, does not interrupt his speech even during a pause, then that person is aimed at constructive cooperation. Anyone who can not listen himself does not need words of other people. Some interdependence does exist. If during verbal conflict after the addressee waits using a pause for reflection and the recipient's reaction, it means most often at this time of "silence" the addressee contemplates to themselves of what that was said as if looking for answers to their own questions even no one expects answers from them. This may cause sincerer communication of 
between the speakers. Conversely, the addressee, which leaves no pause for the recipient, usually has no time to think about their own words nor are able to think about the subject of controversy. Question №3: Are you agree that you need to do pause to bring thoughts and ideas together and give the opponent opportunity to think about your words, or ask you questions? $93 \%$ of respondents replied "yes", $3 \%$ of respondents replied "no", and 4\% of respondents replied "hard to answer”. Question №4: Are you able during conflict in communication to use pauses in speech to gather your own thoughts and allow the opponent to think about your words, or ask you questions? $73 \%$ of respondents replied "yes", $22 \%$ of respondents replied "no", $3 \%$ of respondents replied "at times", $2 \%$ of respondents replied "hard to answer". The difference in data between the "yes" answers are not significant: most respondents indicate that a pause in the verbal conflict is necessary; just as the vast majority of people believe that they can use pauses at the appropriate time, they try to "hold" the pause, though not always successfully. We think that such a small difference can be explained by a high degree of orientation of respondents to the conflict-free communication and incorrect assessment of propose of pauses. Due to "immateriality" of pauses and the terms of the length, the speaker may not always can notice it, so the real "silence" and the idea about "how long he remained silent and was listening to opponent" does not match.

C) So during the survey we tried to calculate how respondents relate to the importance of not to offend the opponent during verbal conflict, does not affect its dignity, by not using negative-evaluative vocabulary (Question №5). 87\% of respondents totally agree with the need, 5\% of respondents understand the possibility, $8 \%$ of respondents could not make a decision. Question №6: Are you able during verbal conflict not insult your opponent? 37\% of respondents replied "yes", 31\% of respondents replied "no", $28 \%$ of respondents replied "at times", 4\% of respondents replied "hard to answer". As you can see, there is variance in the results: most of the people indicate that you should not insult the recipient during verbal conflict, but only about 200 of those respondents believe that it was possible. Such significant difference in data can be associated with two points. At first, verbal abuse it is conscious manifestation of disrespect for another person with reserves of language. However, the "borders" of such disrespect is "blurred". For one person brutal abuse of opponent is normal, for another - the use of the word "stupid" is unacceptable language. At 
second, verbal abuse is closely related to human views on justice. In the everyday consciousness of injustice perceived as a priori clear, but the interpretation of this concept has some difficulties and depends on the personal knowledge of human nature and the principles of the opposite concepts - justice. In the conflict is often difficult to understand on whose side is justice, and hence - questions that everyone is responsible for themselves: Is it fair to answer opponent in such way? Do they deserve such abuse? Therefore, for each respondent meaning of these questions appears a very delicate, tightly "woven" with their various internal beliefs.

D) Question №7 is about the causes of admissibility of verbal abuse an opponent has access to, the motives that govern human conflict, or potentially perceived it as possible. Certain motifs [1, p. 13-21; 3, p. 125-129; 9, p. 83-89] cause the election of a person to use other vocal effects. Usually a person behaves in a particular conflict situation standard with understanding what language "limits" could be used to a particular opponent and what rules will thus violated. We consider that the selection process is particularly important are two factors.

1. The general cultural factor. A social tolerant person as a representative of a community, as a subject of language, has an internal installation in compliance with customs regulations and so on during the conflict that have developed historically. Certain national linguistic traditions act (in the general system of traditions and stereotypes) as a "legislative" language regulator of human behavior in the conflict, so defined and recognized patterns of constructing his texts with different incarnations of speech mechanisms of communicants. Such knowledge is a way to harmonize verbal behavior of each person with communicative behavior of whole nation, the condition of success in communication. Terms of speech etiquette - symbolic generalization of social experience, because social interaction is based on a system of symbols. The social symbol is a reflection of social norms and principles. The importance of understanding national-cultural norms, manners and habits, beliefs, and their transformation in communication; including conflict communication was proven by numerous works of linguists. It is not difficult to recognize: the aggressive behavior of individual's leads to verbal conflict in some different cultures is illegal. Those signs of language, especially in combination with rude gestures or postures breaks cultural rules.

Manifestations of anti-cultural communication, more or less is true for

(C) L. A. Bilokonenko, 2016. 
Ukrainian society. Vulgar offensive language, swearing, profanity, invective to the mother or father, to denote bastard, devilish invective, zoonyms to characterize opponents - it objectively existing examples. The only question is why, under what circumstances an individual decides of his own linguistic behavior contrary to public law. We think that we can talk about two important causes of anti-cultural communication of people in the conflict:

1) Social (features of life activities, social environment, the general level of culture in a social group) and situational (unmet needs, uncertainty, insecurity, social disorientation, mood, lack of awareness) conditions. "Rules" of verbal behavior in conflict these people know, but follow them difficult or even impossible;

2) Need for a certain reaction of person to conflict situation. A person who is forced to resort to anti-cultural communication, making an informed choice between the known rules and "opportunity" to resist increasing aggression with opponent by use of them. This interdependent process: the addresser, who indulges unethical expressions provokes the recipient. The "Rules" of verbal behavior in a conflict recipient are known, but has to temporarily part from them while on the defensive.

If the language of human culture were linked with the mentality of the nation, worldview system of which is based on moral, ethical, aesthetic norms, then the way to constructive behavior people would pass through their successful speech activity. The advantage of this process and that it allows you not only to formulate rules of verbal behavior, but also instructions on how to behave, if you have to break or bend some rules. Therefore, the alignment of the parties during verbal conflict to the general principles and ethical installation is especially important in a society that strives for the harmonious coexistence of its members. Conversely, neglecting social laws deepens the differences between the speakers.

2. Person-centred factor. Individual traits of persons (emotional sensitivity, irritability, aggressiveness, propensity to violence or restraint, balance, flexibility, conformity) - important factors for the course of linguistic conflict. However, the significant factor in the choice of their own human verbal behavior during verbal conflict is their personal life experience. Constructive and destructive conflicts variants regularly replayed in the communication process, although the later would have to "eliminate" out the practice of communication, and for that would be "responded" a life experience. A negative result would have to "teach" a 
person how to avoid conflicts. However, that never happens. Tagging for themselves the limits of verbal conflict on as a result, the person has the right to choose options for implementations of language features into account situational communication. In this case we can speak about personal reasons for someone to resort to anti-cultural communication, in particular it could:

1) be due to a certain complexes of person. The desire to demonstrate "unusualness" at least somehow and prove that "I will not live like everyone else, I will not behave in a certain way, according to the rules", it releases in language deliberately unethical behavior, neglect of public social laws. Such persons have regulator of verbal behavior (you can not intentionally violate something what you do not know about), but the man deliberately suppresses its impulses;

2) be based on individual psychological traits of speakers. Temperament, level of aggressiveness, degree of emotional state, social attitudes cause susceptibility to human conflict behavior. Persons who do not accept the situation that contradicts their principles, unsociable, selfcentred, arrogant, unrestraint feelings, impulsive, selfish, incapable to compromise, with reluctance and inability to consider the views of other people, they live with the motto "I want it to be, so it can't be any different". General "rules" of verbal behavior in conflict are known, but in all practically they do not want to follow them;

3 ) be result of a desire to express an extremely strong emotion. Desire to demonstrate own attitude to the situation a person uses offensive language, profanity, etc., in such way trying to enhance the impact to the interlocutor. "Rules" of verbal behavior in conflict these people know, but "here and now" admit the possibility of violation;

4) be the result of intentional verbal behavior of individuals. Psychologists speak about people who quarrel with the intent to give yourself an emotional discharge (often provoking a "false conflict"). They are some kind of "energy vampires" who relish the conflict, that the opponent is stunned hearing offensive words or insults. After verbal conflict such people are pleased with themselves and their own "ability" to have influence to the addresser. Regulator of verbal behavior in a verbal conflict with such people exists, but it completely being ignored, because for them the most important is the process of torturing a "victim" with attacks and aggression of "vampire";

(C) L. A. Bilokonenko, 2016. 
5) appear (and not only in the conflict) in childhood where rudeness and swearing "comes out" from the home environment, in which the communication between parents and relatives was built in such way. This "lesson" was assimilated by the child that is why the "legislative" regulator of verbal behavior in verbal conflict is extremely weak, and sometimes even missing.

Question №7: Why, in your opinion, during verbal conflict people resorts to non-cultural communication? (You can choose any amount of answers). Results: because the social environment affects people $-39 \%$; because that person has to answer to his opponent's aggression $-26 \%$; because the person does not want to follow social norms and rules $-19 \%$; because people have certain individual psychological and characterological features: aggressive, quarrelsome, offhand, impulsive, etc. - 54\%; because that person shows their extremely strong emotions $-57 \%$; because person is an "energy vampire" who relish conflict and verbal abuse from opponents - 38\%; because person does not know how to behave in other way; because they learnt this strategy in childhood $-22 \%$. We see that for respondents, the most important causes of non-cultural communication is the individual psychological and characterological background and level of emotional person. Indeed, aggressive behavior peculiar to people with emotional instability, offset demonstrative determination. Perhaps that is why a significant percentage of positive reactions fixated on the option of "energy vampire". Formative impact on human social structures are reflected in the methods of education, socialization mechanisms in the behavior proved to be surveyed are not so significant.

E) Process of verbal conflict is also defined on physiological features it communicants. To identify respondents' understanding of the importance of this factor (the relationship between psychophysiological state of the speaker, elected, and communication strategy result of the conflict) was presented in two questions (№№8-9). Question №8: Do you think that during conflict you need to speak calmly, exercise emotional restraint, avoiding claims of a raised voice, or yelling? $92 \%$ of respondents replied "yes", $3 \%$ of respondents replied "no" and 5\% of respondents replied "hard to answer". Question №9: Are you able to speak calmly during the conflict to exercise emotional restraint, avoiding claims of a raised voice, or yelling? $68 \%$ of respondents replied "yes", $13 \%$ of respondents replied "sometimes", $17 \%$ of respondents replied "no", $2 \%$ of respondents replied 
"hard to answer". The variances in the data is significant: more than 500 respondents said that the language conflict must be emotionally balanced, and 445 persons consider that they manage it, though not always. We think that these results are explained unambiguous communication emotional sphere of individual fundamental attitude to the world and to themselves. This attitude is inseparable from the intellectual sphere, identity, and impact on human activity. For contingent surveyed reflected in his own mind such phenomena as objective world conflict clearly linked to the achievement of certain goals in life, an expression of "will", patience, perseverance, self-control, and they declare exactly that.

Questions №1, №3, №5 and №8 have "perfect” character, which is why some reactions have such high percentage of answers "yes". Respondents actively declare their "non-conflict readiness", demonstrate "ability" to treat opponent friendly, carefully and listen to him, to be very prudent, patient, do not approve offences, use negative-evaluation of vocabulary and more. Almost perfect picture of "world" of verbal conflict created by an individual familiar desire to be "socially adequate" member of the community. Even not "to be", but at least "appear". Humanity's life - communication, behavior, actions, and emotions. In humans, there is a need to obtain positive emotional feedback. A person usually receives positive emotions in conflict-free communication (this is normal, because conflict is - uncomfortable), and it becomes a habit. The need to be a "better man" (non-conflict, tolerant) than they actually are - they attempt to feel positive emotions. And also it is "smart" to attempt to gain credibility or love of others or the desire to please everyone or to hide their shortcomings, identity, or self-preservation instinct [4, p. 79]. Everyone understands that the decrease in controlling their speech leads to violations of social norms of behavior, "loss" beyond permissible because most members of this community are trying to avoid. That is why we can see this significant percentage of "non-conflict readiness" of respondents, they declared "compliance".

Other questions (№2, №4, №6 and №9) identify the "real" ability to navigate the course of administration of verbal conflict. It was assumed that respondents who showed their "non-conflict readiness" would match their real communicative action. But the real picture "of the world" of verbal conflict was very varied. It was found that in general, more than $25 \%$ of people are not capable of self-restraint, patience, adequate speech acts, and

(c) L. A. Bilokonenko, 2016. 
so on. But they also declared their peacefulness and tolerance. On the one hand, respondents understood what was received as the "right" answer, at the other side - knowledge and action clearly "disagree".

Psychophysiological design of human life is undergoing some changes. Primarily this is because the increasing socialization affects person's mental functions. Psychologists M. Savchin and L. Vasilenko noted that as an individual age (especially in mature adulthood and old age) comes through a natural "shift" of physiological processes to the direction of "inhibition". It gradually decreases the reaction rate that person needs for answer, slows the process of "processing" information, undergoes transformation in the cognitive sphere, and changes sensory function. But these phenomena are often offset by increased selection accuracy of linguistic reactions associated with the accumulation of experience [7, p. 278-279, 284-285]. Intellectual activity of "aged" people is inextricably linked to their level of education and specific activities. Education with high culture shape the need for knowledge and encourage self-development. The breadth of interests, the desire to share their life experience, their knowledge, help another person, and to be useful to society show that the quality of a person which is perceived as wisdom. This property is also noticeable thanks to a balanced human orientation, comfortable existence where conflict - a phenomenon which is not worth special attention. That is why we believe that we must separately pay attention to the data in the questionnaires of persons with age difference. We queried the responses of two groups of people: respondents at age 18 to 25 years and 50 years. Difference at answers between the ages groups of respondents: question №1 - 2\%, question №2 - 15\%, question №3 - 4\%, question №4 -14\%, question №5 - 12\%, question №6 - 3\%, question №8 $0 \%$, question №9 - 4\%. So older people are not only actively "declare” their "non-conflict readiness", but also confirm it (as it can be possible within the questionnaire).

F) Recognition of verbal conflict begins with an analytical phase, during which the person has resorted to a number of assessment activities. Through life experiences he knows the most typical models of finished: winner - loser, winner - winner, loser - loser. With the perception of conflict, person determines which of the options corresponds to the completion of his interests, although understands that most desirable is not always the most real. Everyone is seeking for victory, because in society 
there is a perception that the strongest wins, one who has power, authority, power, and boldness. Anyone who is afraid of quarrels - are considered weak and would be "defeated". Although there is a lot of those who thinks that verbal conflict can be avoided by tact, the desire to understand the opponent, or respect for them. Question №10: Do you think that conflict will always have winners and losers, 9\% of respondents replied "yes", 88\% respondents replied "no", and 3\% of respondents replied "hard to answer". So for most conflict it is not only fight for victory but try to understand, accept, and perhaps justify the opponent.

G) After the conflict there are two paths. The first path - never communicate with opponents, avoid them; second path - reconciliation that is more productive. Reconciliation is a simple step, but it is that not easy to make it. After all, to reconciliation it is necessary to look at the cause of the conflict, seriously analyze the verbal tactics that led to its escalation, and to understand what words and actions could improve the situation. Although not as exhaustive as conflict reconciliation, it shows a willingness to face the desire to seek a way out of problems. Question №11: Do you tend to look for ways to reconciliation after a conflict, $25 \%$ of respondents replied "always", $75 \%$ respondents replied "sometimes", $0 \%$ respondents replied "never".

Note the ratio in responses to questions №№10-11: respondents do not believe that conflict is always need to be resolved with a model of winner - loser, so they do not seek unquestioning victory and look for ways to reconcile with an opponent.

H) The study of verbal conflict also provides for an appeal to the cognitive categories that are the essence of cognitive activity. Since the speech impact associated with interpersonal social interaction, then we are, first of all, interested at categories related to social cognition. The survey found cognitive categories that, in terms of surveyed, have the greatest impact on the course of the conflict (question №12): general knowledge of humanity about the world $-3 \%$, personal knowledge about the world $32 \%$, life beliefs $-46 \%$, value targets $-53 \%$, self-interests $-16 \%$, selfassessment of the conflict $-19 \%$, religious beliefs $-26 \%$ (respondents could choose multiple answers). Values targeted and identified by respondents as a priority ones, because in the modern Ukrainian society prevails importance of ethnic and cultural factors, so ignoring them is particularly noticeable.

I) Understanding of respondent's pragmatic aspect of verbal conflict

(C) L. A. Bilokonenko, 2016. 
is important. It involves simultaneous interpretation of verbal conflict with two sides. Persons were not always successful in using the language means, to accurately convey information. There are "risk" factors caused by contradictions between the remarks of speakers and their perception. Question №13: What pragmatic factors particularly affect the appearance of verbal interpersonal conflict given the answer: ignoring of one side the meanings of words of other side $-54 \%$, a violation connections between individual expression and behavior $-30 \%$, the content of person expression does not contain all contents that identifies remarks of other side $-16 \%$, inadequate use of interlocutor means of language $-14 \%$, difference in the vocabulary of speakers $-10 \%$, different emotional evaluation of linguistic signs each of each side $-33 \%$, the reluctance of people to speak on a particular topic or substantially certain topics $-34 \%$, availability of hidden information at replicas of one side $-50 \%$; incivility in communication, language and speech violations of rules $-38 \%$ (respondents were able to choose multiple answers). For respondents the most important factors are those that related to deliberate inattention to the words of man, and the conditions when the information is not given in fact with half-truths or deception.

Conclusion. Sociolinguistic study showed that the majority of respondents represented themselves as non-conflict people. In today's communication environment, Ukrainian people realize that they must empathize with the interlocutor, try to correctly use pauses, consider the use of inappropriate verbiage to not insult your opponent, they are not focused to win with absolute certainty, and are likely to choose reconciliation. In verbal conflict the persons pay special attention to the absence of values of the targeted speaker, recognize that ignoring the words of an opponent, or hiding information may escalate verbal conflict. General "ideology" behavior of the person in the language conflict created under the influence of updated knowledge about his "vitality", which is acting as objective basis for determining the meaning and significance of this phenomenon. Respondents recognize the appearance of linguistic conflict traits of people, their culture and language preferences, social and psychological factors; and conflict-free communication associated with language, culture and communication. Fairness and respect for identifying the communication partner that opposed categorical, rudeness and hostility, show the other side of each speaker - dignity. This option of verbal behavior when people 
focus efforts on mutual understanding, can demonstrate improved mental features of the Ukrainian people; compassion, kindness, good humor, and empathy - all that is semantically associated with tolerance, expresses the idea of overcoming the conflict. Consensus opens the way to pluralism in linguistic and cultural structures.

\section{Literature}

1. Богушевич Д. Г. Опыт классификации эпизодов вербального общения / Д. Г. Богушевич // Язык, общение: процессы и единицы. - Калинин : КГУ, 1988. С. 13-21.

2. Гуйванюк Н. В. Мовна толерантність як соціолінгвістична категорія / Н. В. Гуйванюк // Вісник Львівського ун-ту. - 2006. - Вип. 38. Ч. ІІ. - С. 37-46.

3. Крысин Л. П. Социолингвистические аспекты изучения современного русского языка / Л. П. Крысин. - М. : Наука, 1989. - 186 с.

4. Лобанова А. С. Феномен соціальної мімікрії / А. С. Лобанова. - К. : Інститут соціології, 2004. - 300 c.

5. Масенко Л. Т. Нариси з соціолінгвістики / Л. Т. Масенко. - К. : Видавничий дім «Києво-Могилянська академія», 2010. -243 с.

6. Мацюк Г. П. До витоків соціолінгвістики: Соціологічний напрям у мовознавстві / Г. П. Мацюк. - Львів : ВЦ ЛНУ ім. І. Франка, 2008. - 432 с.

7. Савчин М. В. Вікова психологія : [навч. посіб.] / М. В. Савчин, Л. П. Василенко. - К. : Академвидав, 2006. -359 с.

8. Соколова С. Типи мовної поведінки в сучасному слов'янському білінгвальному мегаполісі / С. Соколова, В. Труб, Л. Масенко, О. Данилевська, О. Руда // Українські обрії. - К., 2013.- Мовознавство. - Вип. 6, ч. 1. - С. 173-196.

9. Сухих С. А. Прагматическое моделирование коммуникативного процесса / С. А. Сухих, В. В. Зеленская. - Краснодар : КГУ, 1998. - 160 с.

Стаття надійшла до редакиії 05.10.2015 p. 